\title{
Successful Conservative Surgical Treatment of Ameloblastic Fibroma in the Posterior Maxilla : A Case Report
}

\author{
Youngeun Lee', Hyojung Ahn', Sooeon Lee', Euncheol Kim², Sungchul Choi' \\ 'Department of Pediatric Dentistry, School of dentistry, Kyung Hee University \\ ${ }^{2}$ Department of Maxillofacial Tissue Regeneration, School of Dentistry and Research Center for Tooth and \\ Periodontal Tissue Regeneration, School of Dentistry, Kyung Hee University
}

\begin{abstract}
Ameloblastic fibroma $(\mathrm{AF})$ is a rare odontogenic ectomesenchymal tumor that is frequently seen in the first two decades of life, and occurs in the mandible. The most proper management of AF has been a recent topic of debate because of its recurrence and malignant transformation. This report describes AF in a 4-year-old male, which was a unilocular radiolucency on the maxillary right primary molar area with a scalloped border and corticated margin. The tumor was treated conservatively with enucleation and curettage, and the decision was made to preserve the right primary second molar. A biopsy confirmed it as AF. During the 43 months of followup, the patient had no evidence of recurrence or malignant transformation. Moreover, the radiographic examination revealed the generation of tooth germ to be a permanent second premolar. This report shows a case of AF in the posterior maxilla of a 4-year-old boy and discusses the conservative therapeutic approach to this tumor. Therefore, the age of the patients should be an important consideration when choosing conservative or radical surgery in a young AF patient.
\end{abstract}

Key words : Ameloblastic fibroma, Mixed odontogenic tumor, Enucleation

\section{I . Introduction}

Ameloblastic fibroma (AF) is a tumor of mixed connective and odontogenic tissue origin, most commonly found in younger age groups, between 15 and 25 years of age, with varied sex prediction from no preference to males being more affected than females ${ }^{1.2}$. The posterior mandibular area is the most common anatomic site of $\mathrm{AF}^{3)}$.

There is controversy in the literature as to whether treatment should be conservative or aggressive. AF $\mathrm{ex}^{-}$ hibits somewhat slow clinical growth, is well encapsulated and shows an innocuous benign behavior, according to most studies ${ }^{3-5)}$. A conservative treatment strategy, such as enucleation and curettage, is generally the treatment of choice, and the prognosis of these tumors is reported to be good $^{3.5)}$. On the other hand, some researchers believe that AF is more aggressive than had been thought and a more radical therapy is needed on the basis of reviewing recurrent or malignantly transformed cases in the literature ${ }^{6.7)}$. According to this opinion, a more radical excision, block resection or segmental resection is recommended ${ }^{8}$.

This report describes a rare case of AF, occurred in the posterior maxilla of a 4-year-old boy. The lesion was successfully treated conservatively.

\section{Corresponding author : Sungchul Choi}

Department of Pediatric Dentistry and Institute of Oral Biology, School of Dentistry, Kyung Hee University, 130-702, Seoul, Republic of Korea

Tel: +82 29589339 / Fax: +82 29657247 / E-mail: pedochoi@khu.ac.kr

Received May 23, 2013 / Revised September 12, 2013 / Accepted September 12, 2013

※ This research was supported by the Basic Science Research Program through the National Research Foundation of Korea, funded by the Ministry of Education, Science, and Technology (2011-0013331). 


\section{Case Report}

A 4-year-old boy was referred to the Department of Pediatric Dentistry at the Kyung Hee Dental Hospital, Seoul, Republic of Korea, by his family dentist for evaluation of unerupted maxillary primary right molars. The medical, social and family histories were unremarkable. The intraoral examination revealed firm swelling on the buccal aspect of the gingiva in the primary right maxillary molar region (Fig. 1A). No discharge, redness, or fluctuation could be elicited from this area. The initial intraoral and panoramic radiography showed a well-defined unilocular radiolucent lesion on the right primary molar area (Fig. 1B, C), and confirmed the presence of the unerupted teeth, and the missing tooth germ of the right permanent first and second premolars (Fig. 1C). Cone beam computed tomography (CBCT) showed a well-defined monolocular radiolucent lesion around the primary first molar with a scalloped border and corticated margin (Fig. 2). Sinus floor elevation, reactive mucosal thickening, and the partially indistinct cortication of the maxillary sinus floor could be observed (Fig. 2).

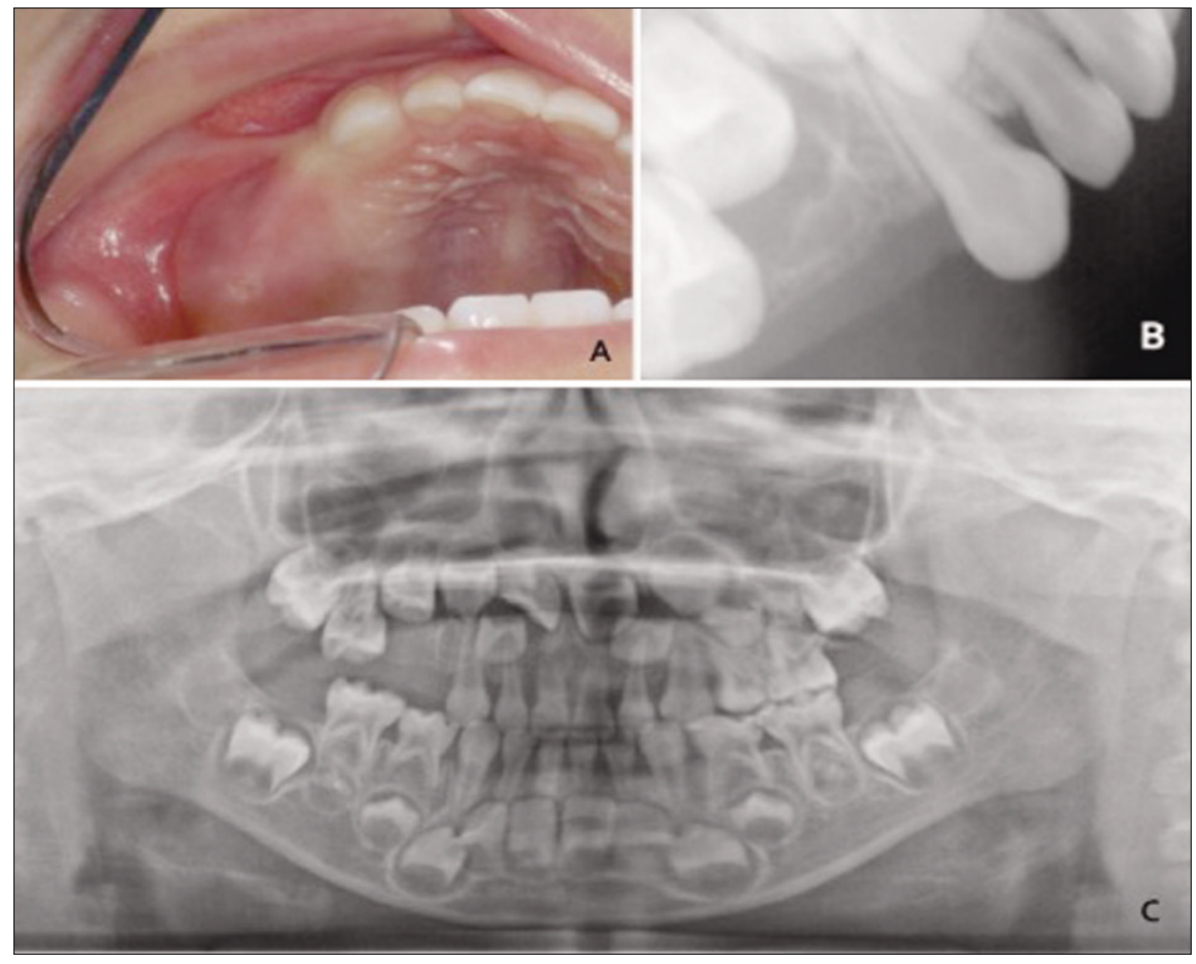

Fig. 1. (A) Initial intraoral view. Firm swelling on the buccal aspect of the gingiva was normal in color and consistency was observed. (B) Initial periapical view. (C) Initial panoramic view. Radiographic examination showed a well-defined unilocular radiolucent lesion on the right primary molar area. The disturbed eruption of the right primary molars and missing tooth germ of the right permanent first and second premolars could be confirmed.

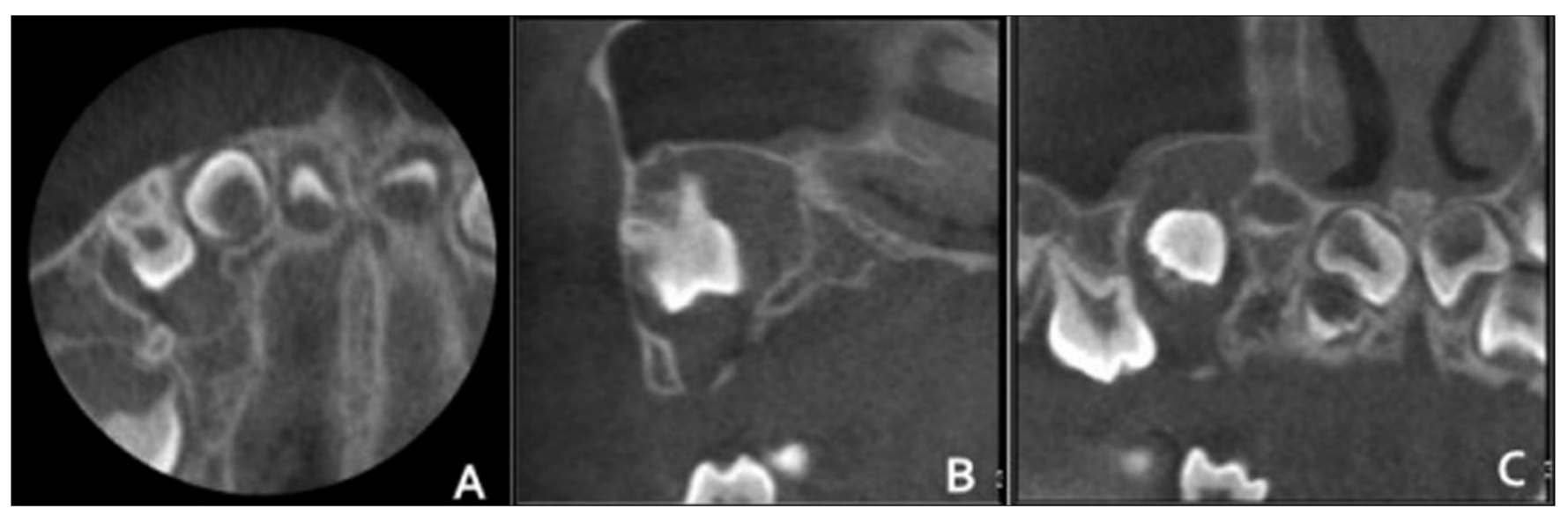

Fig. 2. CBCT view. (A) The transverse view showed a well-defined monolocular radiolucent lesion around the primary first molar with a scalloped border and corticated margin. (B) Sagittal view. The lesion was extended to the palatal side and sinus floor. (C) Coronal view. Sinus floor elevation and reactive mucosal thickening could be observed. The maxillary sinus floor showed partially indistinct cortication. 
Magnetic Resonance Imaging (MRI) was taken to differentiate the lesion with the odontogenic cyst. The T1weighted image (WI) of the MRI showed medium signal intensity, which confirmed the CBCT (Fig. 3A). In the T2WI, it had a higher signal intensity than the muscle (Fig. 3B). However, a gadolinium-enhanced T1WI showed an inhomogeneous high signal intensity, which had been enhanced by the contrast agent (Fig. 3C). The clinical and radiological diagnosis was AF. The cytologic smear by needle aspiration biopsy showed many lymphocytes and a few histiocytes without malignant cells (Fig. $5 \mathrm{~A}$ ). Considering the patient's age and extent of surgery, the patient was treated by enucleation and curettage under general anesthesia, instead of resection. The right primary first molar was also enucleated, whereas the decision was made to preserve the right primary second molar. The right primary second molar was exposed and a space maintainer was placed after it reached the occlusal plane (Fig. 4A, B). The pathological examination of the specimen revealed strands, cords, and islands of odontogenic epithelium in a primitive connective tissue stroma resembling dental papilla (Fig. 5B). Although a cell-free zone and/or a zone of hyalinization were occasionally found at the epithelial-mesenchymal interface, no hard tooth structures were detected (Fig. 5C). Based on these results, the tumor was diagnosed as $\mathrm{AF}$.

The patient was followed postoperatively for 43 months, but there was no sign of recurrence and malignant transformation. Postoperative panoramic radiography demonstrated completion of the bone healing with a new generation of tooth germ under the root of the right primary second molar area (Fig. 6).

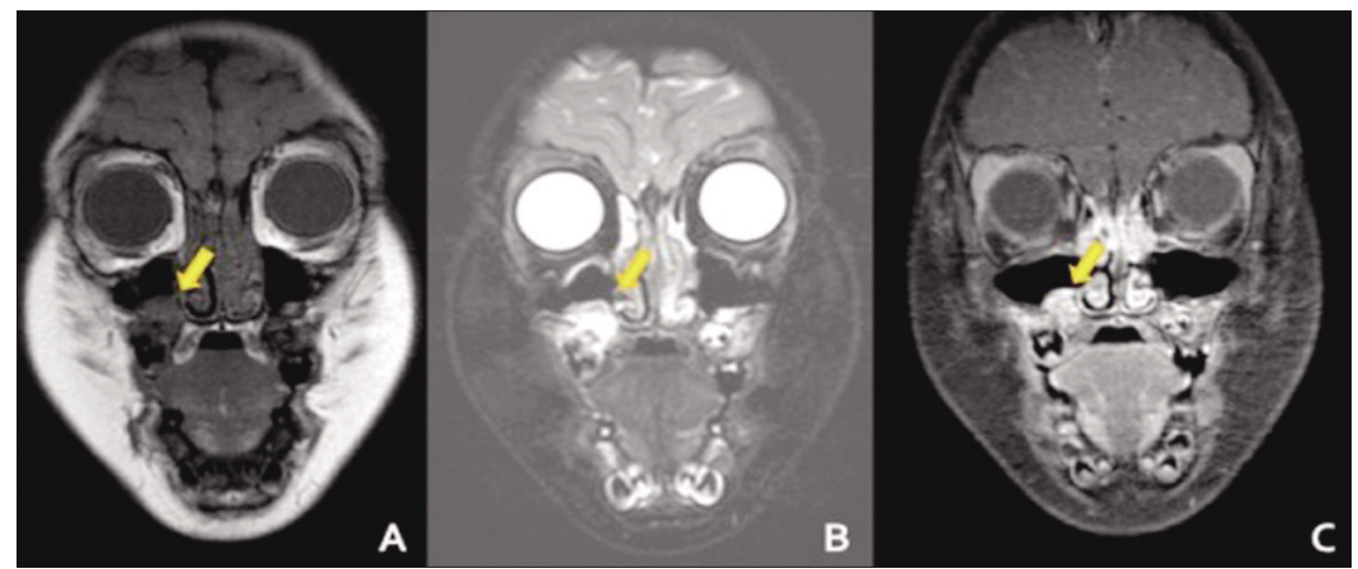

Fig. 3. (A) In the T1-weighted images, a low signal appeared in the area consistent with the CT image. (B) In the T2weighted images, a high signal appeared. (C) The same area showed an inhomogeneous enhanced signal in the gadolinium-T1-weighted image.

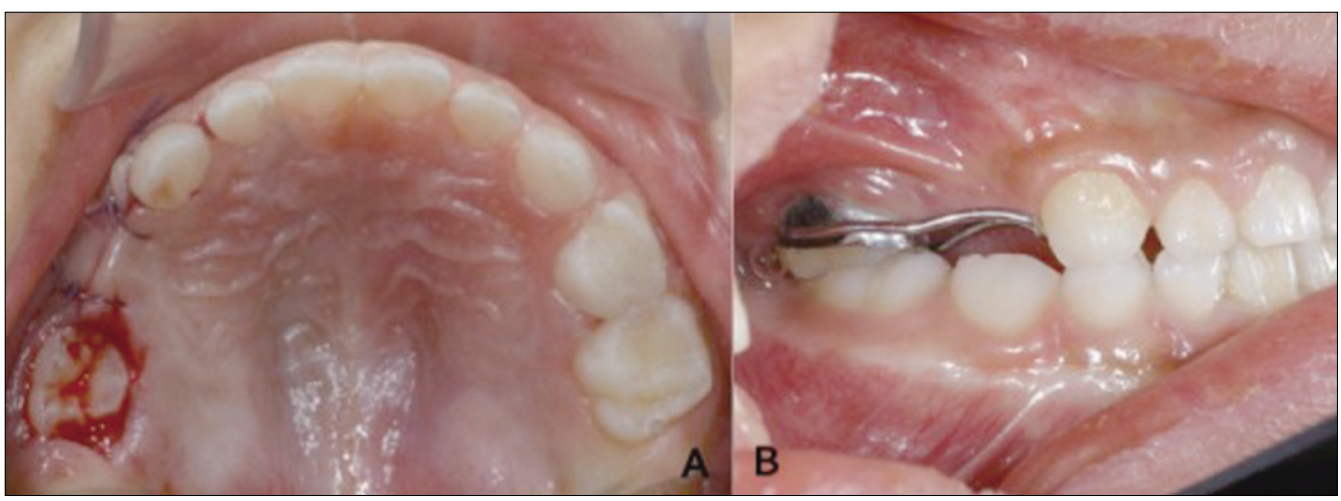

Fig. 4. (A) The lesion was completely enucleated and curetted. (B) A space maintainer was placed 1 month after surgery. 


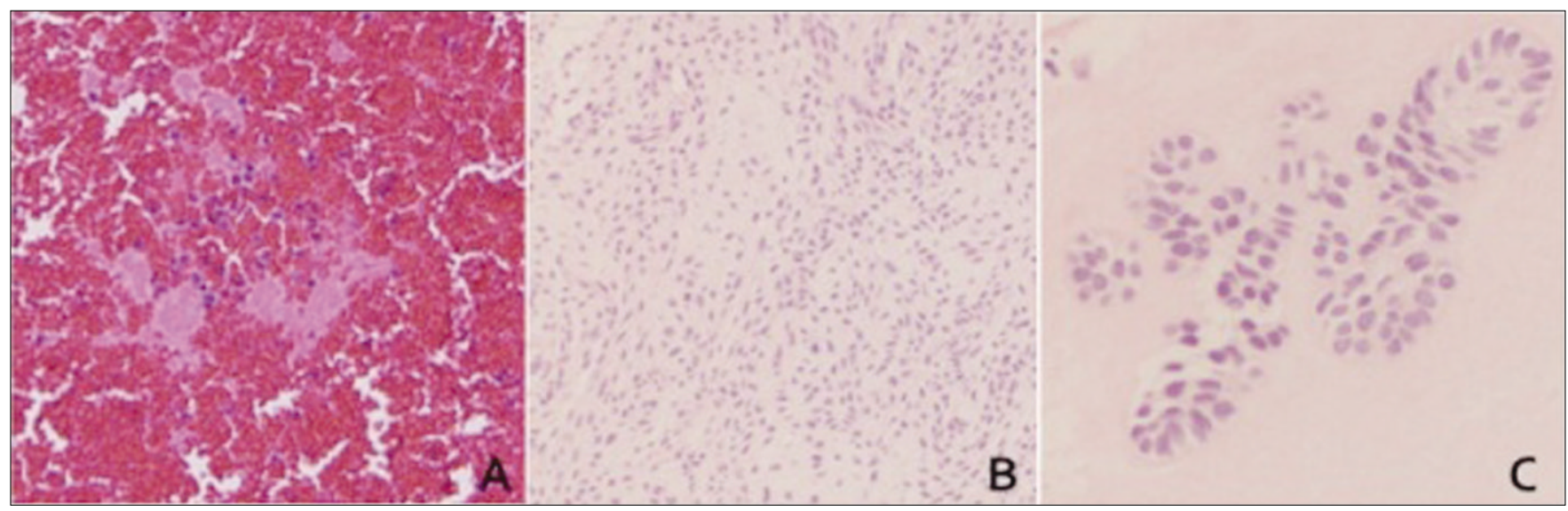

Fig. 5. (A) A cytologic smear showed no malignant cells. (B, C) The stroma showed a fibromyxoid appearance with clusters of epithelial cells forming solid nests and glands $[(\mathrm{A}, \mathrm{B})$ magnification $\times 100$; (C) magnification $\times 400$; stain: $\mathrm{H} \& \mathrm{E})$.

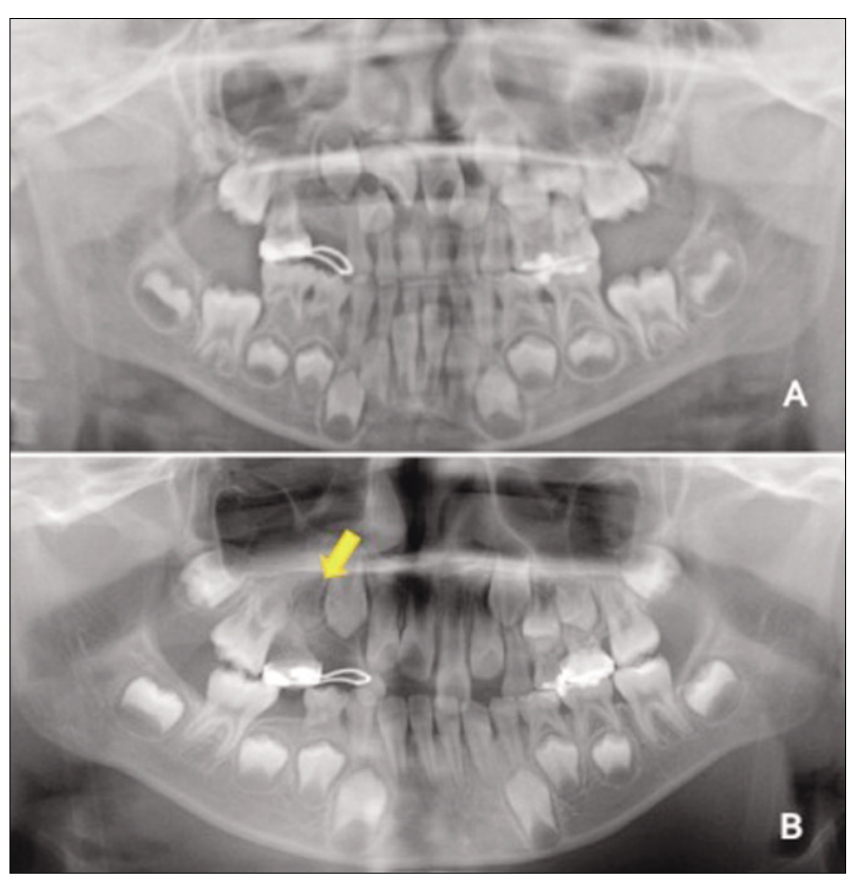

Fig. 6. Panoramic view (A) 18 months, (B) 36 months after the operation. The radiographic image around the root of the right primary second molar revealed the generation of the tooth germ (arrow).

\section{III . Discussion}

Ameloblastic fibroma is a rare tumor, accounting for only $2.5 \%$ of odontogenic tumors ${ }^{2.5}$. The average age of presentation is in the teenage years ${ }^{2.5}$. The majority of $\mathrm{AF}$ has been reported in the posterior mandible ${ }^{3)}$. The incidence rate of $\mathrm{AF}$ in posterior maxillary area is only half of that of posterior mandibular area ${ }^{4}$. According to the data analysis from an extensive review of the pub- lished studies on AF in the English literature (19492005), 13.8\% (17/123) of the cases was diagnosed as $\mathrm{AF}$ in children under five ${ }^{3)}$. Among them, maxillary $\mathrm{AF}$ was only $4.9 \%(6 / 123)^{3)}$. In this point of view, the rarity of this case, maxillary AF in a 4-year-old boy, can be focused. Patients with maxillary AF usually present with intraoral findings including swelling of the alveolar process and noneruption of teeth ${ }^{4)}$, symptoms which also occur in our patient. This addresses the importance of routine oral examination in childhood and adolescence, which should be carried out thoroughly on both soft and hard tissues of the oral cavity.

Radiographically, AF is a unilocular lesion, occasionally multilocular when larger, with a smooth well-demarcated border ${ }^{2.5)}$. Because lesions are frequently associated with unerupted teeth they may initially be interpreted as dentigerous cysts ${ }^{9}$. In our patient's panoramic view and CBCT, well-defined unilocular radiolucency with a corticated margin and no expansion of the cortical plate in the maxillary posterior area were observed. Although CBCT can provide a good quality of image of the calcified tissue, the soft tissue is not distinguishable with this method. On the other hand, the MRI can discriminate a subtle difference among the soft tissues. This was why we chose the MRI to differentiate this lesion with the odontogenic cyst. Usually, the tumor in the head and neck region showed low signal intensity in the T1WI and a high signal in the T2WI ${ }^{10)}$. These findings agreed with our results of the MRI. However, it is important to note that the cyst has a low signal intensity in T1WI and high signal intensity in T2WI. To tell the difference, a gadolinium-enhanced MRI should be used. Hisatomi et 
al. ${ }^{11)}$ reported that an odontogenic tumor could be distinguished from an odontogenic cyst, which shows peripheral enhancement but no central enhancement. Our case showed inhomogeneous enhancement in the lesion in gadolinium-enhanced T1WI, enabling us to diagnose it as a tumor rather than a cyst.

Aspiration biopsy is a safe, quick and reliable procedure that can immediately differentiate inflammatory, reactive, cystic and neoplastic processes ${ }^{12)}$. A positive malignancy in this test can be considered as a final diagnosis and treatment instituted accordingly. For the screening procedure, a needle aspiration biopsy was performed in this case. As a result, a negative fine needle aspiration (FNA) with inflammatory processes was observed. Scher et al. ${ }^{13)}$ stated that $13 \%$ of unsatisfactory FNA and $21 \%$ of negative FNA turned out to be a falsenegative. Therefore, a biopsy is recommended in negative and unsatisfactory FNA.

$\mathrm{AF}$ is a mixed tumor with both epithelial and mesenchymal neoplastic proliferation. The epithelial component is described histologically as strands of cuboidal cells surrounding a reticulum similar to the source of embryonic enamel, which are ameloblasts. The mesenchymal component looks similar to embryonic dental pulp but with less collagen. Ameloblastic fibroma has a slower growth rate than ameloblastoma and is less infiltrative. This results in a slow growing tumor that may expand bone and have smooth borders ${ }^{3)}$.

There is controversy over the management of AF. Both radical and conservative approaches are suggested by different authors. A wide excision of the tumor has been recommended unless the extent of surgery would result in significant cosmetic deformity ${ }^{9.14)}$. Others support enucleation or curettage as the initial treatment with a modified block resection reserved for recurrence ${ }^{4)}$. Furthermore, a majority of patients $(91.5 \%)$ with $\mathrm{AF}$ were treated by conservative surgery ${ }^{3}$. We opted for enucleation and curettage of the tumor with preservation of the maxillary right primary second molar because of its location, and cosmetic deformity and age. The radiographic image around the root of the right primary second molar revealed a putative permanent second premolar tooth germ, 3 years following the operation. This result supports that a conservative surgical approach is meaningful in young patients. Chen at al. . $^{3)}$ emphasized the importance of the patient's age during treatment planning. Considering a significantly lower rate of malignant transformation, it was recommended to treat pa- tients younger than 22 years by conservative strategy and by stepwise treatment principle with multiple recurrence $^{3)}$. However, recurrence rate, estimated as being between 1.8 and 43.5\%, long-term recall protocol is also important $^{14,15)}$. It was reported that recurrence-free period range from 1month to 96 months with a mean of 33.2 months $^{3)}$. Also, conservative treatment with long-term (at least 10 years) annual follow-up evaluation indicating no recurrence is recommended ${ }^{5}$. This case was followed up during 43 months without recurrence. The patient will continue to be evaluated annually.

\section{Summary}

In this study, we report our experience with a case of $\mathrm{AF}$ in a 4-year-old boy treated with conservative surgical enucleation and preservation of an impacted upper right second molar. After 43 months of follow-up, there were no signs of recurrence and complete spontaneous eruption of the preserved tooth was observed. Although its tendency to recur and undergo malignant transformation makes dentists choose more aggressive surgical $\mathrm{ex}^{-}$ cision, a conservative treatment strategy, such as enucleation and curettage, seems to be the most appropriate therapeutic option, especially for young patients.

\section{References}

1. Costa DO, Alves AT, Lourenco Sde Q et al. : Maxillary ameloblastic fibroma: a case report. Braz Dent J, 22:171-174, 2011.

2. Takeda Y : Ameloblastic fibroma and related lesions: current pathologic concept. Oral Oncol, 35:535-40, 1999.

3. Chen Y, Wang JM, Li TJ : Ameloblastic fibroma: A review of published studies with special reference to its nature and biological behavior. Oral Oncol, 43:960-9, 2007.

4. Neville BW, Damm DD, Allen CM, Bouquot JE : Oral and Maxillofacial Pathology. 3rd ed., Saunders, St. Louis, 719-720, 2002.

5. Mosby EL, Russell D, Barker BF et al. : Ameloblastic fibroma in a 7-week-old infant : A case report and review of the literature. $J$ oral Maxillofac Surg, 56: 368-372, 1998.

6. Reichart PA, Zobl H : Transformation of ameloblastic fibroma to fibrosarcoma. Report of a case. Int $J$ Oral Surg, 7:403-7, 1978. 
7. Takeda Y, Kaneko R, Suzuki A : Ameloblastic fibrosarcoma in the maxilla, malignant transformation of ameloblastic fibroma. Virchows Arch A Pathol Anat Histopathol, 404:253-63, 1984.

8. Kousar A, Hosein MM, Ahmed Z, Minhas K : Rapid sarcomatous transformation of an ameloblastic fibroma of the mandible: case report and literature review. Oral Surg Oral Med Oral Pathol Oral Radiol Endod, 108:80-5, 2009.

9. Cohen DM, Bhattacharyya I : Ameloblastic fibroma, ameloblastic fibro-odontoma, and odontoma. Oral Maxillofac Surg Clin North Am, 16:375-84, 2004.

10. Langlais RP, van Rensburg LJ, Nortje CJ et al. : Magnetic resonance imaging in dentistry. Dent Clin North Am, 44:411-26, 2000.
11. Hisatomi M, Asaumi J, Kishi K et al. : MR imaging of epithelial cysts of the oral and maxillofacial region. Eur J Radiol, 48:178-82, 2003.

12. Silverman : Oral Cancer, Fifth Edition - American Cancer Society, Atlas of Clinical Oncology, BC Decker, 60-61, 2003.

13. Scher RL, Oostingh PE, Levine PA et al. : Role of fine-needle aspiration biopsy in the diagnosis of lesions of the oral cavity, oropharynx and nasopharynx. Cancer, 62:2602-6, 1988.

14. Zallen RD, Preskar MH, McClary SA : Ameloblastic fibroma. J Oral Maxillofac Surg, 40: 513-517, 1982.

15. Trodahl JN : Ameloblastic fibroma. A survey of cas ${ }^{-}$ es from the Armed Forces Institute of Pathology. Oral Surg Oral Med Oral Pathol, 33:547-58, 1972. 
국문초록

\section{상악 구치부에 발생한 법랑모세포섬유종의 성공적인 보존적 수술 : 증례 보고 \\ 이영은 ${ }^{1} \cdot$ 안효정 $^{1} \cdot$ 이수언 $^{1} \cdot$ 김은철 $^{2} \cdot$ 최성철 $^{1}$}

${ }^{1}$ 경희대학교 치의학전문대학원 소아치과학교실, ${ }^{2}$ 경희대학교 치의학전문대학원 조직학교실

법랑모세포섬유종은 드물게 나타나는 진성 혼합 치성 종양으로 10 20대의 어린 환자의 하악에서 호발하는 경향을 보인 다. 법랑모세포섬유종의 치료는 종양부위의 제거를 원칙으로 하고 있다. 종양부의 제거는 보존적 방법과 광범위한 제거를 선 택할 수 있으나 이는 아직 논쟁이 되는 사항이며 저자에 따라 주장하는 바가 다르다. 이는 법랑모세포섬유종의 재발률과 악 성으로의 전이 가능성 때문이다.

본 증례는 상악 우측 유구치의 미맹출을 주소로 내원한 4세 환아에서 발생한 법랑모세포섬유종에 대하여 묘사하고 있다. 법랑모세포섬유종을 적출술과 소파술을 이용하여 성공적으로 치료 하였기에 이에 대한 문헌 고찰 및 증례를 보고하고자 한다.

주요어: 법랑모세포섬유종, 진성 혼합 치성 종양, 적출술 